\title{
FOURTEEN AND SIX C/SEC POSITIVE BURSTS IN COMATOSE PATIENTS *
}

\author{
T. YAMADA ${ }^{\ddagger}$, R.P. TUCKER and K.A. KOOI
}

Electroencephalographic Laboratory, Neuropsychiatric Institute, The University of Michigan Medical Center, Ann Arbor, Mich. 48104 (U.S.A.)

(Accepted for publication: December 4, 1975)

There have been numerous contributions regarding the clinical and etiologic significance of 14 and $6 \mathrm{c} / \mathrm{sec}$ positive bursts, aptly summarized by Gibbs and Gibbs $(1952,1963)$, Poser and Ziegler (1958), Henry (1963) and Hughes (1965), but none of the cases discussed by these authors were of an acute nature. Silverman (1964) observed 14 and $6 \mathrm{c} / \mathrm{sec}$ positive bursts in a patient with a coma due to infectious hepatitis and he stressed the rarity of this finding in an acutely ill, comatose subject. The purpose of this communication is to describe the presence and discuss the possible clinical significance of 14 and $6 \mathrm{c} / \mathrm{sec}$ positive bursts in acute coma due to Reye's syndrome.

\section{Material and method}

A total of ten consecutive patients with Reye's syndrome, age 7-14 years, were treated at the University of Michigan Mott Children's Hospital during the early part of 1974. From one to five EEGs were obtained from each patient, using an 8-channel Grass electroencephalograph. A total of 30 EEGs were recorded. Scalp electrodes were placed according to the 10-20 International system.

The EEG abnormalities were classified into

* Part of the paper was read in the Central Association of Electroencephalographers (U.S.A.), 1975.

+ Current address: Electroencephalographic Laboratory, Department of Neurology, University of Iowa Hospitals and Clinics, Iowa City, Iowa 52242 (U.S.A.). six grades (Aoki and Lombroso 1973): grade I: predominant theta and less alpha; grade II: predominant theta and less delta; grade III: diffuse high voltage rhythmic or arrhythmic delta activity with no or little theta activity; grade IV: diffuse mostly low voltage delta activity with no or little theta activity; grade V: nearly isoelectric activity; grade VI: electrocerebral silence.

The diagnosis of Reye's syndrome was made on the basis of the clinical presentation, a course consistent with this syndrome (Reye et al. 1963; Bradford and Latham 1967; Huttenlocher et al. 1969), and abnormal laboratory findings, specifically the blood ammonia level, serum glutamic oxaloacetic transaminase (SGOT) and serum glutamic pyruvic transaminase (SGPT).

Coma was graded into four stages (Silverman 1963):

Stage I: Arousal and cooperation at times were possible; if unstimulated, the patient was lethargic and tended to lapse into a comatose state.

Stage II: Arousal was difficult and was only possible after repeated and strong stimuli.

Stage III: All communication with the patient was lost except for a protopathic avoidance to noxious stimuli.

Stage IV: No behavioral responses to any external stimuli were observable.

\section{Results}

Three cases will be decribed in detail. 
Case 1

A 10-year-old boy who was previously in good health developed a cough, malaise, and a low grade fever 5 days prior to admission. A few days later severe vomiting started and persisted until admission. A day prior to admission, the parents noticed that the patient was confused and irritable. The examination on admission revealed the patient to be delirious with agitated behavior and the patient then rapidly became stuporous. His temperature was $101^{\circ} \mathrm{F}$ (rectal); pulse rate was $150 / \mathrm{min}$; respiratory rate was $38 / \mathrm{min}$; blood pressue was $120 / 80 \mathrm{~mm} \mathrm{Hg}$. The liver edge was palpable and the spleen was slightly enlarged. His pupils were dilated but of equal size and reactive to light. There was a mild blurring of the disc margins bilaterally by funduscopic examination. He had increased muscle tone, hyperactive reflexes and bilateral Babinski signs.

Laboratory studies on admission revealed a serum ammonia level of $320 \mu \mathrm{g} \%$ (control 30 $\mu \mathrm{g} \%$ ), SGOT of $110 \mathrm{IU}$ and SGPT of $480 \mathrm{IU}$. His prothrombin level was $33 \%$ of normal. A lumbar puncture was not performed because of suspected increased intracranial pressure.

A few hours after admission, the patient became comatose and responded to pain in a decerebrate manner.

The first EEG was obtained $12 \mathrm{~h}$ after admission when the patient was in stage III coma with a dilated, non-reactive pupil on the left. The EEG was a grade IV with intermittent, diffuse $0.5-1 \mathrm{c} / \mathrm{sec}$ delta waves of less than $100 \mu \mathrm{V}$ in amplitude (Fig. 1, A). Episodic 14 $\mathrm{c} / \mathrm{sec}$ positive bursts were noted in the bioccipital region. The patient was then placed on a subdural pressure monitoring system and intracranial pressure was continuously monitored (Kindt et al. 1975). The second EEG was taken the following day when the patient showed some improvemt. The EEG was grade III with higher amplitude and shorter wave length delta waves as compared to the first EEG (Fig. 1, $B$ ). Again, positive bursts were noted. The patient steadily improved and upon discharge he was neurologically normal except for a partial 3rd cranial nerve paresis on the left side. EEGs were obtained on the 5th, 6 th and 12 th day of hospitalization which were grades II, I and borderline, respectively. None of the last three EEGs showed positive bursts (Fig. 1, C).

Case 2

A 9-year-old male was well until 7 days prior to admission when he developed "flu-like" symptoms characterized by low-grade fever, cough, myalgia and lethargy. Two days afterwards, the patient began vomiting. On the night prior to admission, the patient was noted to be agitated and confused with occasional visual and auditory hallucinations.

On admission, the patient exhibited alternating agitation and stupor. His blood pressure was $140 / 95 \mathrm{~mm} \mathrm{Hg}$; pulse rate was $80 / \mathrm{min}$; respiratory rate was $24 / \mathrm{min}$. Pupils were slightly dilated but equal and reacted briskly to light. Funduscopic examination was normal. Slight hepatomegaly was noted. He moved all extremities spontaneously. Deep tendon reflexes were slightly increased, and there were bilateral Babinski signs. Laboratory data disclosed a SGOT of $1210 \mathrm{IU}$, a SGPT of $1430 \mathrm{IU}$ and a serum ammonia of $100 \mu \mathrm{g} \%$ (control 30 $\mu \mathrm{g} \%$ ). The opening pressure on lumbar puncture was $100 \mathrm{~mm}$ water; the spinal fluid was clear and colorless with no cells; cerebrospinal fluid protein was $17 \mathrm{mg} \%$; cerebrospinal fluid glucose was $97 \%$. The EEG taken $6 \mathrm{~h}$ after admission when the patient was in stage II coma was a grade III characterized by high amplitude 2-3 c/sec delta waves (Fig. 2). Prominent 14 $\mathrm{c} / \mathrm{sec}$ positive bursts with some $6 \mathrm{c} / \mathrm{sec}$ components were noted in occipital and temporal regions. The patient showed steady improvement and was discharged 2 weeks after admission.

\section{Case 3}

A previously healthy 8-year-old male developed fever and a sore throat 5 days prior to admission. Three days later he began vomiting repeatedly. He became progressively delirious 

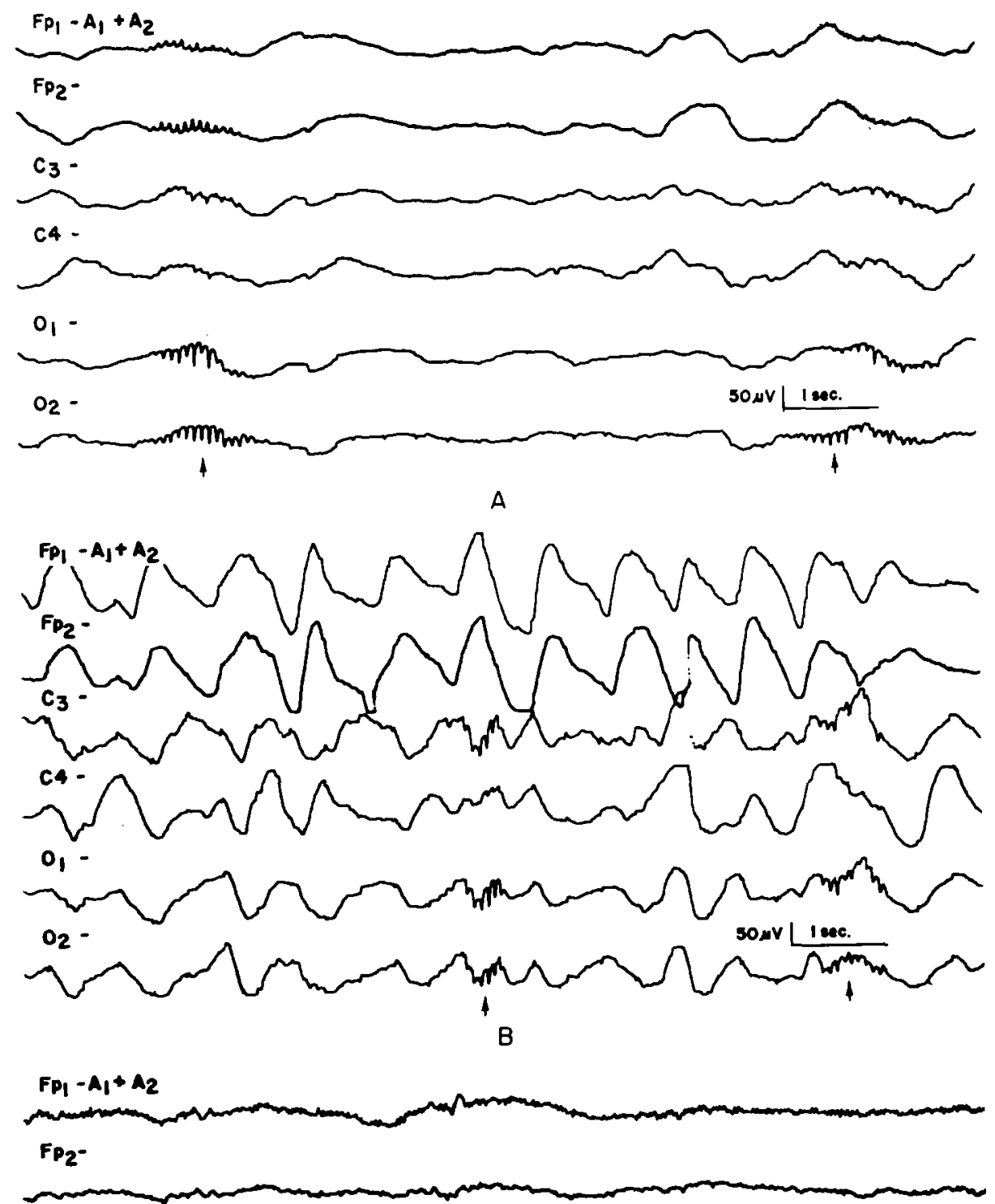

$$
\mathrm{C}_{3} \text { - }
$$

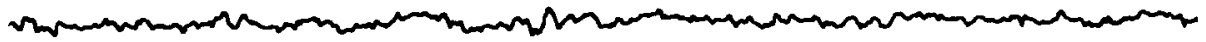

c4.

(1)

$0_{1}$ -

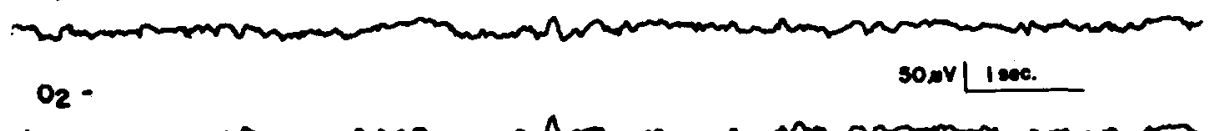

C

Fig. 1. $A$ : Grade IV EEG when patient was in stage III coma. Note 14 and $6 \mathrm{c} / \mathrm{sec}$ positive bursts (arrow). $B$ : Grade III EEG when patient was in stage II coma on the following day. Note $14 \mathrm{c} / \mathrm{sec}$ positive bursts (arrow). $C$ : Improvement of EEG on 12 th day of hospitalization. Patient was alert. Note absence of positive bursts (light stages of sleep). 


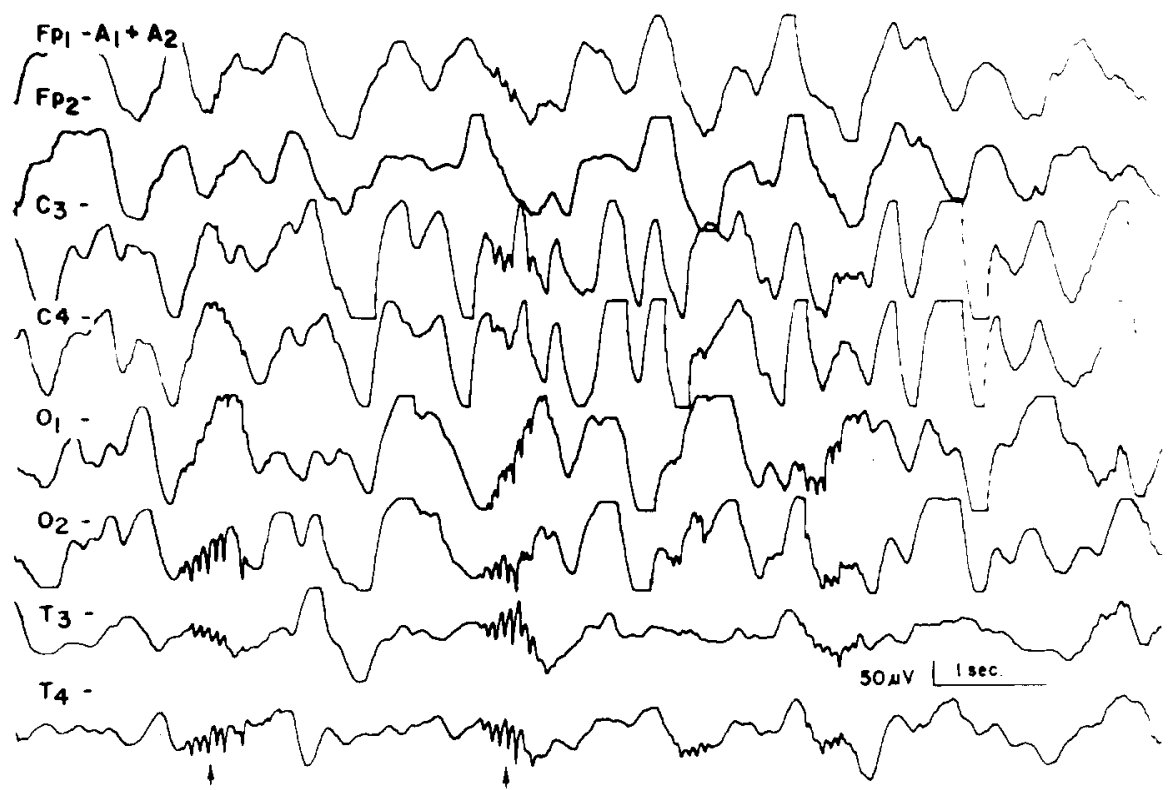

Fig. 2. Grade III EEG when patient was in stage II coma. Note 14 and $6 \mathrm{c} / \mathrm{sec}$ positive bursts (arrow).

and agitated. On admission, his temperature was $98^{\circ} \mathrm{F}$ (rectal); pulse rate was $100 / \mathrm{min}$; respiratory rate was $32 / \mathrm{min}$; blood pressure was 124/62 mm Hg.

The patient's behavior was characterized by periods of agitation and delirium alternating with periods of stupor. His pupils were slightly enlarged but of equal size and reactive to light. Funduscopic examination revealed sharp disc margins. He had a mild systolic murmur. The liver and spleen were not palpable. He had increased muscle tone, hyperactive reflexes, sustained ankle clonus and bilateral Babinski signs. Laboratory findings revealed a SGOT of $180 \mathrm{IU}$, a SGPT of $400 \mathrm{IU}$, a prothrombin level of $40 \%$ of normal and a serum ammonia of $140 \mu \mathrm{g} \%$ (control $40 \mu \mathrm{g} \%$ ). Lumbar puncture revealed clear and colorless cerebrospinal fluid with no cells, cerebrospinal fluid protein of 15 $\mathrm{mg} \%$ and sugar of $95 \mathrm{mg} \%$. The first EEG was taken $6 \mathrm{~h}$ after admission when the patient was in stage II coma. Prominent $14 \mathrm{c} / \mathrm{sec}$ positive bursts were noted in the right cental, temporal and occipital regions (Fig. $3, A$ ). Intermittent sleep spindles were also observed in the central area. At this time strong alerting stimuli abolished both sleep spindles and positive bursts but high voltage rhythmic delta slow waves remained dominant. The EEG was graded III. Second and third EEGs were obtained on the 2nd and 7th days of hospitalization and were graded II and borderline, respectively. Positive bursts were no longer present in either EEG (Fig. $3, B$ ). The patient improved, and he was discharged after 8 days of hospitalization with normal motor and mental function.

\section{Cases 4 and 5}

These patients were 12- and 7-year-old males who were in stage III coma on admission. Their first EEGs were grade IV, and episodic $14 \mathrm{c} / \mathrm{sec}$ positive bursts were noted superimposed on the background of low-voltage delta waves, similar to the EEG of Fig. 1, A. Both patients expired on the third day of hospitalization.

The EEGs of five of ten patients who were in various stages of coma revealed 14 and 6 $\mathrm{c} / \mathrm{sec}$ positive bursts in a background of diffuse delta waves of variable frequency and ampli- 


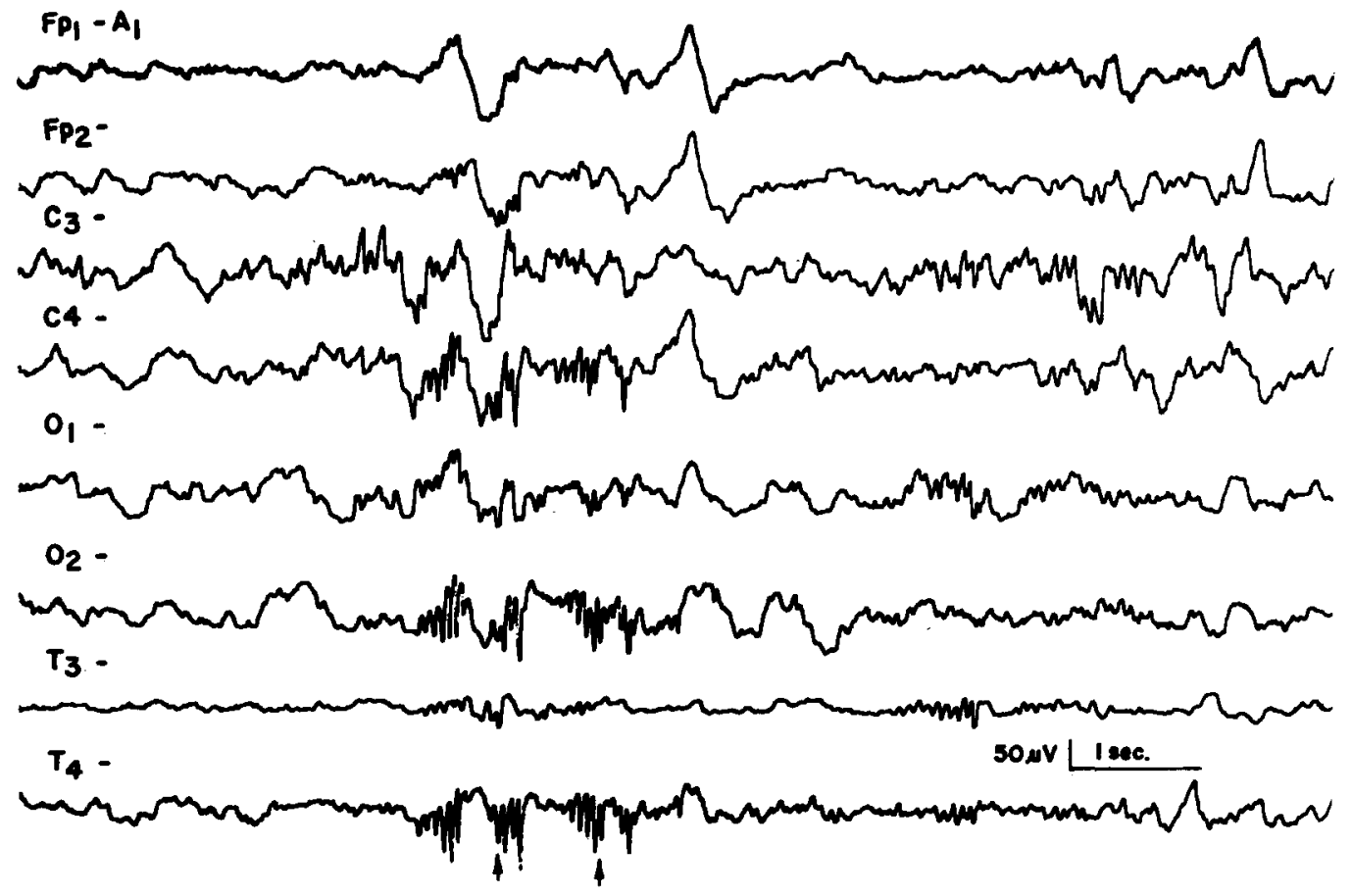

A

$F_{P_{1}-A_{2}}$

$\mathrm{FP}_{2}-$

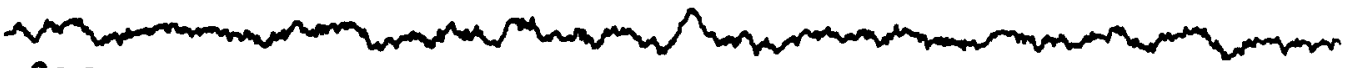
$\mathrm{C}_{3}-$

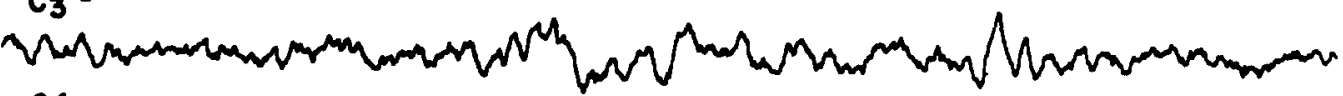

c4 -

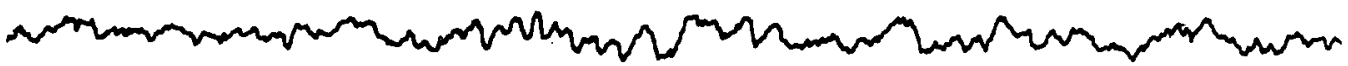

01 .

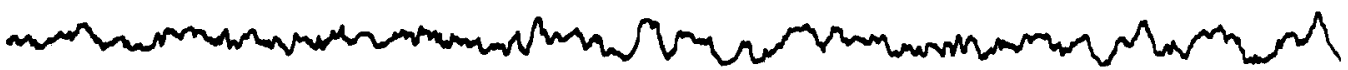

$\mathrm{O}_{2}$ -

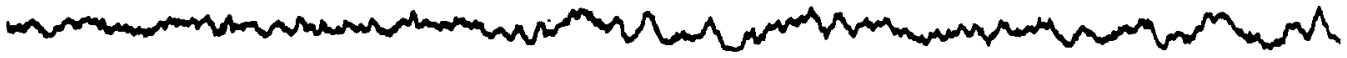

$\mathrm{T}_{3}$ -

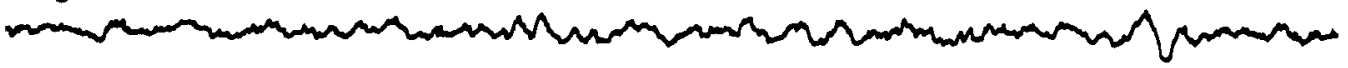

$T_{4}$ -

souv | 1 see.

(1)

B

Fig. 3. A: $14 \mathrm{c} / \mathrm{sec}$ positive bursts (arrow) appear when the EEG resembles spindle stage of sleep. Note sleep spindles on the right side of the figure $\left(\mathrm{C}_{3}\right)$. Patient was in stage II coma. $B$ : Improvement of the EEG on $7 \mathrm{th}$ day of hospitalization. Patient was alert. Positive bursts were not seen (light stage of sleep). 
TABLE I

\begin{tabular}{rlrllllll}
\hline Case No. & Sex & $\begin{array}{l}\text { Age } \\
\text { (years) }\end{array}$ & \multicolumn{2}{l}{ EEG grade } & & & Outcome \\
\hline 1 & M & 10 & IV] & III & II & I & B & $\begin{array}{l}\text { Survived } \\
\text { Survived }\end{array}$ \\
2 & M & 9 & III] & & & & & Survived \\
3 & M & 9 & III & II & B & & & Died \\
4 & M & 12 & IV & V & VI & & Died \\
5 & M & 7 & IV] & VI & VI & & Survived \\
6 & M & 14 & II & I & & & & Died \\
7 & F & 13 & V & VI & VI & & Died \\
8 & F & 13 & V & VI & VI & & VI & Died \\
9 & M & 7 & III & IV & VI & & Died \\
10 & F & 13 & V & VI & VI & & \\
\hline
\end{tabular}

B: Borderline.

: EEG with 14 and $6 \mathrm{c} / \mathrm{sec}$ positive burst.

tude (Fig. 1, $A$ and $B, 2 ; 3, A$ ). All the positive bursts but one (Case 2) were $14 \mathrm{c} / \mathrm{sec}$ without $6 \mathrm{c} / \mathrm{sec}$ components. Table I shows the gradings of the EEGs and the outcomes of the ten patients. The patients were divided into two groups with group 1 (Cases $1-5$ ) having 14 $\mathrm{c} / \mathrm{sec}$ positive bursts and group 2 (Cases 6-10) being without $14 \mathrm{c} / \mathrm{sec}$ positive bursts.

Out of six EEGs with positive bursts, three were grade IV (Cases 1, 4, 5), three were grade III (Cases 1, 2, 3). Three of the second group had grade $V$ EEGs on admission with subsequent isoelectric EEGs (Cases 7, 8, 10). Only one case (Case 9), which had a similar degree of abnormality to the first group, failed to reveal the positive bursts. As a whole, six of eight EEGs graded from III to IV showed the $14 \mathrm{c} / \mathrm{sec}$ positive bursts. When the EEG became grade $\mathrm{V}$ or worse, positive bursts were no longer present (Cases 4,5). Disappearance of positive bursts was also noted upon improvement (Cases 1, 3).

There were three survivors from group 1 and one from group 2.

\section{Discussion}

Since the early studies by Berger (1932) and Gibbs et al. (1937), diffuse EEG slowing has been regarded as characteristic of a variety of comatose states. Davis and Davis (1939), Schwab (1951) and Strauss et al. (1952) considered that the delta activity in comatose states was similar to that of deep sleep. Comatose states may be associated with a multitude of abnormal wave forms other than delta waves (Fischgold and Bounes 1946; Mathis et al. 1957; Loeb 1958; Fischgold and Mathis 1959). The presence of various sleep patterns such as sleep spindles, vertex sharp waves and $\mathrm{K}$-complexes have been described in patients with coma of diverse etiologies (Jasper and Van Buren 1953. Chatrian et al. 1963; Silverman 1963). However, the presence of 14 and $6 \mathrm{c} / \mathrm{sec}$ positive bursts in comatose patients has been seldom reported in the literature. This is true even though positive bursts are most commonly seen during drowsiness or early sleep and certain workers have regarded the bursts as a distorted form of sleep pattern (Gibbs and Gibbs 1951) or even a type of sleep spindle (Kooi 1971). Silverman (1964) described one case of infectious hepatitis in which the 14 and $6 \mathrm{c} / \mathrm{sec}$ positive bursts were present during comatose state. Poser and Ziegler (1958) included a single case of hepatic coma due to Laennec's cirrhosis among 136 patients with various diagnosis who had positive bursts in their EEGs. In our own experience, positive bursts are also extremely uncommon in coma in patients of any age, al- 
though the bursts are a common finding in normal adolescence. We have recently seen a single case of $6 \mathrm{c} / \mathrm{sec}$ positive bursts in a 40 year-old man with hepatic coma.

In view of the prevalent opinion that 14 and $6 \mathrm{c} / \mathrm{sec}$ positive bursts are generally found in normal, young persons (Walter et al. 1960; Lombroso et al. 1966; Eeg-Olofsson 1971). and that the present group of patients range from 7 to 14 years of age, it may be that the positive bursts were preserved in these young comatose patients as a type of sleep pattern. Sleep spindles were noticed in some cases of Reye's syndrome studied by Aoki and Lombroso (1973) and also in one of our cases (Case 3 ). In the latter case, positive bursts were noted only when the EEG resembled sleep because of the presence of intermittent sleep spindles.

Although the etiology and pathogenesis of the Reye's syndrome have yet to be elucidated, several studies have implicated short-chain fatty acids as potential toxins (Bourgeois et al. 1971; David et al. 1972; Trauner et al. 1972) and elevated concentration of serum shortchain fatty acid in Reye's syndrome was reported (Trauner et al. 1975). Administration of short-chain fatty acids to experimental animals was shown to induce sleep patterns in EEGs and a further increase of dosage to result in irreversible coma (White and Samson 1956). These experimental results further support the observation that some of the EEG features of Reye's syndrome resemble sleep patterns.

However, the following reasons raise the possibility that the positive bursts may not be simply preserved but are enhanced in some stages of coma in Reye's syndrome: (1) This is an unusual prominence and frequency of occurrence of positive bursts in the face of actual reduction of other patterns characteristic of light to moderately deep sleep (Fig. 1, A, Cases 4 and 5. (2) Subsidence of positive bursts upon improvement is observed (Fig. 1, $C ; 3, B$ ). This finding was also noted in the case reported by Silverman. (3) Positive bursts are found in association with EEG patterns resembling deep-level sleep, whereas they are usually seen with lighter levels of sleep in normal youths (Fig. 1, B;2).

It is of further interest to note that our cases, Silverman's case, and Poser and Ziegler's case all had hepatic dysfunction. A causal relationship between hepatic disorder and positive bursts cannot be established with certainty because of the limited number of cases reported to date. The data suggest the need for further observations relative to a possible correlation between positive bursts and etiology of coma.

\section{Summary}

Of ten patients with Reye's syndrome, there were five with stage II or III coma where EEGs revealed $14 \mathrm{c} / \mathrm{sec}$ positive bursts in a background of diffuse delta waves. Positive bursts disappeared upon EEG improvement in two survivors and when the EEG became nearly isoelectric in two other patients.

Although 14 and $6 \mathrm{c} / \mathrm{sec}$ positive bursts are seen commonly during sleep in normal young persons, their occurrence in association with diffuse delta waves in acutely ill, comatose patients has been rarely reported.

It is not certain whether the present findings should be regarded as selective preservation of a type of sleep pattern or whether there are special factors that enhance positive bursts in stage II or III coma of Reye's syndrome.

\section{Résumé}

Bouffées positives de 14 et $6 \mathrm{c} / \mathrm{sec}$ chez les malades dans le coma

Chez 10 malades présentant un syndrome de Reye, 5 cas ont présenté un coma de stade II ou III dans lequel l'EEG a montré des bouffées positives de $14 \mathrm{c} / \mathrm{sec}$ sur un fond d'activité delta diffuse. Ces bouffées positives disparaissent lorsque l'EEG s'améliore chez deux survivants et lorsque l'EEG devient pratiquement isoélectrique chez deux autres malades. 
Bien que les bouffées positives de 14 et 6 $\mathrm{c} / \mathrm{sec}$ s'observent habituellement au cours du sommeil chez les sujets jeunes normaux, leur survenue en association avec des ondes delta diffuses chez des malades aigus comateux n'a été qu'exceptionnellement rapportée.

Il n'est pas certain que les données observées ici puissent être considérées comme une conservation élective d'un certain type de pattern de sommeil, ni qu'il existe des facteurs particuliers qui augmentent les bouffées positives au cours de comas aux stades II ou III de syndrome de Reye.

\section{References}

Aoki, Y. and Lombroso, C.T. Prognostic value of electroencephalography in Reye's syndrome. Neurology (Minneap.), 1973, 23: 333-343.

Berger, H. Über das Elektrenkephalogramm des Menschen. IV. Arch. Psychiat. Nervenkr., 1932, 97 : 6-26.

Bourgeois, C., Olson, L., Comer, D., Evans, H., Keshamras, N., Cotton, R., Grossman, R. and Smith, T. Encephalopathy and fatty degeneration of the viscera: A clinico-pathologic analysis of forty cases. Amer. J. clin. Path., 1971, 56: 558-571.

Bradford, W.D. and Latham W.C. Acute encephalopathy and fatty hepatomegaly. Amer. J. Dis. Child., 1967, 114: 152-156.

Chatrian, G.E., White, L.E. and Daly, D. Electroencephalographic patterns resembling those of sleep in certain comatose states after injuries to head. Electroenceph. clin. Neurophysiol., 1963, 15:272280.

David, R.B., Trauner, D.A., Madge, G.E., Mamunes, P. and Brown, R.E. Reye's syndrome: Lipid studies in man and animals. Neurology (Minneap.), 1972, 22: 398 .

Davis, P.A. and Davis, H. The electrical activity of the brain: Its relation to physiologic states and to states of impaired consciousness. Res. Publ. Ass. nerv. ment. Dis., 1939, 19: 50-80.

Eeg-Olofsson, O. The development of the electroencephalogram in normal children from the age of 1 through 15 years: 14 and $6 \mathrm{~Hz}$ positive spike phenomenon. Neuropädiatrie, 1971, 2: 405-427.

Fischgold, H. et Bounes, G. Exploration électroencéphalographique des états comateux. Sem. Hôp. Paris, 1946, $22: 1245-1247$.

Fischgold, H. et Mathis, P. Obnubilations, comas et stupeurs: Etudes électroencéphalographique. Electroenceph. clin. Neurophysiol., 1959, Suppl. 11, $124 \mathrm{p}$.

Gibbs, E.L. and Gibbs, F.A. Electroencephalographic evidence of thalamic and hypothalamic epilepsy. Neurology (Minneap.), 1951, 1: 136-144.

Gibbs, F.A. and Gibbs, E.L. In Atlas of electroencephalography, Vol. 2. Addison Wesley Press, Reading, Mass., $1952,422 \mathrm{p}$.

Gibbs, F.A. and Gibbs, E.L. Fourteen and six per second positive spikes. Electroenceph. clin. Neurophysiol., 1963, 15: 553-558.

Gibbs, F.A., Gibbs, E.L. and Lennox, W.G. Effect on the electroencephalogram of certain drugs which influence nervous activity. Arch. intern. Med., 1937, 60: 154-166.

Henry, C.E. Positive spike discharges in the EEG and behavior abnormality. In G.H. Glaser (Ed.), EEG and behavior. Basic Books, New York, 1963: 315344.

Hughes, J.R. A review of the positive spike phenomenon. In W.P. Wilson (Ed.), Applications of electroencephalography in psychiatry. Duke University Press, Durham, N.C., 1965: 54-101.

Huttenlocher, P.R., Schwartz, A.D. and Klatskin, G. Reye's syndrome: Ammonia intoxication as a possible factor in the encephalopathy. Pediatrics, 1969, 43: 443-454.

Jasper, H.H. and Van Buren, J. Interrelationships between cortex and subcortical structures: Clinical electroencephalographic studies. Electroenceph. clin. Neurophysiol., 1953, Suppl. 4: 168-202.

Kindt, G.W., Waldman, J., Kohl, S., Baublis, J. and Tucker, R.P. Intracranial pressure in Reye's syndrome: Monitoring and control. J. Amer. med. Ass., 1975, 231: 822-825.

Kooi, K.A. Fundamentals of electroencephalography. Harper and Row, New York, N.Y., 1971, 60 p.

Loeb, C. Electroencephalographic changes during the state of coma. Electroenceph. clin. Neurophysiol., $1958,10: 589-606$.

Lombroso, C.T., Schwartz, I.H., Clark, D.M., Muench, H. and Barry, J. Ctenoids in healthy youth: Controlled study of 14- and 6-per-second positive spiking. Neurology (Minneap.), 1966, 16 : 1152-1158.

Mathis, P., Torubia, H. et Fischgold, H. Réactivité, périodicité et corrélation cortico-cardio-respiratoire dans le coma. In H. Fischgold and H. Gastaut (Eds.), Conditionnement et réactivité en électroencéphalographie. Electroenceph. clin. Neurophysiol., 1957, Suppl. 6: 453-462.

Poser, C.M. and Ziegler, D.K. Clinical significance of 14 and 6 per second positive spike complexes. Neurology (Minneap.), 1958, 8: 903-912.

Reye, R.D.C., Morgan, G. and Baral, J. Encephalopathy and fatty degeneration of the viscera. A disease entity in dhildren. Lancet, 1963, 2: 749-752.

Schwab, R.S. Electroencephalography in clinical practice. Sanders, Philadelphia, Pa., 1951, 195 p.

Silverman, D. Retrospective study of the EEG in coma. Electroenceph. clin. Neurophysiol., 1963, 15: 486-503. 
Silverman, D. Fourteen and six per second positive spike pattern in a patient with hepatic coma. Electroenceph. clin. Neurophysiol., 1964, 16: 395398.

Strauss, H., Ostow, M. and Greenstein, L. Diagnostic electroencephalography. Grune and Stratton, New York, 1952, 282 p.

Trauner, D.A., David, R.B., Madge, G., Brown, R.E. and Mamunes, P. Reye's syndrome and free fatty acid induced coma. Pediat. Res., 1972, 6: 329.
Trauner, D.A., Nyhan, W.L. and Sweetman, L. Shortchain organic acidemia and Reye's syndrome. Neurology (Minneap.), 1975, 25: 296-298. Walter, R.D., Colbert, E.G., Koegler, R.R., Palmer, J. and Bond, P.M. A controlled study of the fourteenand six-per-second EEG pattern. Arch. gen. Psychiat., 1960, 2 : 559-566.

White, R.P. and Samson, F.E. Effects of fatty acid anions on the electroencephalogram of unanesthetized rabbits. Amer. J. Physiol., 1956, 186: 271274. 